\title{
Trace element problems on Scottish soils
}

\author{
R. L. Mitchell
}

The Macaulay Institute for Soil Research, Craigiebuckler, Aberdeen, AB9 2QJ, Scotland

\section{Summary}

The soils of Scotland are very varied and relatively young, having developed from glacial tills laid down some 12000 years ago. The complex geology has resulted in soil parent materials with very varied trace element contents, usually related directly to those of the parent rock. Many of these trace elements are mobilized readily in soils with impeded pedological drainage. Deficiencies of cobalt, copper, manganese, boron and selenium have been recorded in plants or animals, while the levels of molybdenum and nickel are occasionally high enough to cause problems in animals and plants, respectively. The trace element status of a soil can seldom be related directly to its total content: an extraction technique, appropriate to the element in question, is used to assess availability to plants. The Soil Survey of Scotland has reached a stage at which the soil associations and soil series can be used to assess the probable trace element situation, particularly on arable land. The determination of trace element contents of soils and plants is carried out largely by spectrochemical methods.

\section{Introduction}

Scotland has long been recognized to be a classical area for the study of geology and was the home of many pioneers of that science. In the late 18 th century and early 19th century such men as Hutton (1726-1797), Miller (1802-1856), Lyell (1797-1875) and Geikie (1835-1924) made many of the advances that established the basic principles, taking advantage of the material for fruitful study that the exceedingly diverse igneous, metamorphic and sedimentary rocks, often subjected to complicated thrusting, folding and, later, glaciation, provide in a compact area. In addition, the topography is complex and the climate temperate oceanic, giving rise to varied rock-weathering processes and the ready accumulation of peat deposits: as a consequence the soil parent materials are of the most diverse types. The complete glaciation of the country some 12000 years ago removed most of the soils that then existed and left glacial till from which the present soils are being formed.

These parent materials, that were derived, through boulder clays, from ultrabasic to acid igneous rocks, from argillaceous to arenaceous and calcareous sediments, from various gneisses, schists and slates, or from mixed tills derived from almost any mixture of these, have given rise to soils that have developed under almost all possible conditions of pedological drainage except aridity. The geochemical factors governing the distribution of trace elements in rocks, which were established largely by Goldschmidt and his co-workers (see Goldschmidt, 1954), ensure that in such parent materials wide ranges of content of most trace elements are to be anticipated, while the pedological 
conditions are often those which encourage their mobilization and increase their availability to plants (Mitchell, 1964a, 1972a).

Little was known about the distribution of these trace elements, or of their effects on plants and animals, when in the spring of 1934, Adriaan Schuffelen and I met as post-graduate students in Georg Wiegner's Agrikulturchemisches Laboratorium in the Zürich E.T.H., a training ground which, particularly in the decade 1926-1936, attracted workers from many countries.

Until Lundegårdh demonstrated, almost 50 years ago, that it was possible successfully to apply spectrochemical methods to the systematic analysis of solutions, the study of major and trace elements in soils, plants and biological materials was a long and often inexact process. One of the first to appreciate the possibilities of these methods was Hans Pallmann in Wiegner's laboratory, and it was my introduction to such methods there, in company with A. C. Schuffelen, that led directly to their adoption at the Macaulay Institute in Aberdeen in 1935, to the subsequent development of many specialized techniques for soil and plant analysis (Mitchell, 1964b) and so to the present extensive knowledge of the distribution of trace elements in Scottish soils, with which I have been closely associated. It is interesting to recall that Professor Schuffelen's Doctorate Thesis (Utrecht, 1940), which concerned quantitative analysis with flame spectra, also stemmed from that period in Zürich. This occasion provides an appropriate opportunity to make available a brief summary of the nature and diversity of the trace element problems that have arisen on Scottish soils and to indicate the measures that are taken to diagnose and counter them, so that they can be compared with those that have arisen in the Netherlands and elsewhere over the same period. No attempt is made to discuss the nature of the plant and animal implications.

\section{Elements with which problems have arisen}

\section{Boron}

In 1934 there were in progress throughout the world numerous studies on the biological importance of such trace elements as copper, manganese and boron, but in Scotland only boron was then being studied systematically and the first definite establishment of a trace element disorder here was the attribution of raan or brown-heart in Swedish turnips to a deficiency of boron in the soil by O'Brien \& Dennis (1935), as a result of work from 1932 onwards. Attempts to clarify fully the soil aspects of boron deficiency have not been completely successful. Some factor other than the level of extractable boron and soil $\mathrm{pH}$ is apparently involved, as, on suspect soils, the disorder does not appear regularly each year. Some indication of soil boron status is given by the content of water-extractable boron, the critical value being around $0.5 \mathrm{mg} / \mathrm{kg}$, but it has been suggested that moisture level and/or microbiological activity may also be involved. Cereals usually contain $1-5 \mathrm{mg}$ boron per $\mathrm{kg}$ and other crops up to 50 $\mathrm{mg} / \mathrm{kg}$, but information on diagnostic levels for deficiency is not available for Scottish conditions. In practice boronated fertilizers at a rate of $10-30 \mathrm{~kg}$ borax per hectare are usually applied to susceptible crops, such as turnips or sugar-beet, on soils known to carry boron-deficient crops. These soils are generally derived from arenaceous parent materials low in boron, including some granites and sandstones. Boron in soil extracts or plant material is determined either by chemical methods or by porous-cup solutionspark or rotating-disk interrupted-arc spectrochemical methods, to which reference is made below. 


\section{Cobalt}

In 1934 interest was reawakening in the animal disorder now attributed to cobalt deficiency and first recorded in the monograph entitled The Shepherd's Guide, in which, in 1807, James Hogg, a Scottish poet and sheep-farmer, included a chapter on Pining and Daising of Sheep. The symptoms were described and the practice of transferring affected animals to better land to effect a cure recommended. This therapy survived in Scotland until the cause was established in the late 1930's, but a few years earlier the work, based on reports from overseas, was centered on iron. The first Scottish investigation of a soil factor responsible for pining in ruminants, or indeed of any other such animal disorder, was probably that of Greig et al. (1933) in a study, in which the author was involved, of its incidence on the calcareous shell sands, or machairs, of Tiree, one of the Western Isles of Scotland. The true cause of the disorder was meantime established in Australia and New Zealand in 1935-36 (see Mitchell, 1972b) and confirmatory work commenced in Scotland. It was soon evident that soils derived from a number of different parent materials, particularly sandstones, granites and other arenaceous rocks, might not contain enough available cobalt to carry pasture herbage with sufficient cobalt (around $0.08 \mathrm{mg} / \mathrm{kg}$ dry matter) to support healthy ruminant animals, particularly sheep. In addition to the arenaceous hill-lands of Hogg's Border Country, cobalt pining in sheep has been identified and treated on soils from almost all parts of Scotland, notably those on sandstones around the Moray Firth, on granites in Aberdeenshire and Galloway, on schistose rocks of the Northern Highlands and on the shell sands of the Western Isles. The geological and topographical complexity has resulted in occurrences of cobalt deficiency throughout the country. Although it does not occur, particularly on arable soils, over very extensive areas around each location, locally it can be severe and treatment can at least double lamb live-weight at six months; hence some characterization of the soils involved, or some means of diagnostic identification, became necessary.

Forty years ago, analytical techniques, even for total contents of cobalt in soils and plants, were tedious and imprecise, while little was known of cobalt availability to plants as assessed by soil extraction. These lines of work have been pursued with my colleagues at the Macaulay Institute, and, later extended to many other trace elements, have lead to a reasonably complete understanding of the behaviour of trace elements in Scottish soils. While the Lundegårdh flame technique soon provided a method for serial analysis of potassium, sodium, calcium, magnesium, strontium and manganese in soil and plant extracts, and led to the establishment of an extensive soil advisory service in collaboration with the North of Scottland College of Agriculture, it was not capable of determining cobalt and other trace elements at the levels normally found in soils or plants. At the instigation of V. M. Goldschmidt, an arc emission method for determination of such elements at the appropriate total levels in rocks and minerals had meantime been developed by Mannkopff and Peters in Göttingen (see Mitchell, 1964b). This cathode-layer-arc technique was adopted and modified to provide the necessary sensitivity and accuracy. It was soon being used to assess total contents in soils directly down to the $1 \mathrm{mg} / \mathrm{kg}$ level, and, with a chemical concentration pretreatment (Scott \& Mitchell, 1943), enabling cobalt to be determined in soils and plants down to the $0.02 \mathrm{mg} / \mathrm{kg}$ level, to an accuracy of $\pm 10 \%$ or better.

This procedure provided a means of assessing the level of available cobalt in soil by extraction with dilute acetic acid. It was established that under Scottish conditions, in arable mineral soils of $\mathrm{pH}$ below 6 , a mixed pasture herbage could carry healthy sheep only if the extractable cobalt level were not below $0.3 \mathrm{mg} / \mathrm{kg}$. Higher contents 
were required at higher $\mathrm{pH}$ values or in soils rich in organic matter. The disorder on arable land could be prevented by treatment of the soil with cobaltized superphosphate providing $2 \mathrm{lb} \mathrm{CoSO}_{4} \cdot 6 \mathrm{H}_{2} \mathrm{O}$ per acre $(2.2 \mathrm{~kg} / \mathrm{ha})$. This amounts to the addition of $0.25 \mathrm{mg} \mathrm{Co} / \mathrm{kg}$ soil to a depth of $20 \mathrm{~cm}$, and in the young Scottish soils persists for several years. The rapid immobilization of added cobalt by manganese minerals reported in Australia has not been encountered in Scotland. The effect of cobalt in controlling pining in sheep on deficient soils was studied by Stewart et al. (1941, 1942, 1946).

On hill-land carrying fewer sheep, such soil treatment may not be practicable and direct veterinary measures may be required, but the cobalt status of the soil and of the vegetation, suitably interpreted, can still be used for diagnostic purposes.

\section{Nickel}

Although iron deficiency of plants has been reported elsewhere, there has been no recorded instance of such deficiency in Scotland, and no conclusive evidence of the essentiality of nickel in plants or animals has so far been produced. Nickel does however occur in an available form in amounts toxic to plants in some Scottish soils derived from ultrabasic igneous rocks, generally under conditions of impeded drainage. The nickel-rich ferromagnesian minerals such as olivine in such soils weather readily and a considerable proportion of the total nickel content (up to $500 \mathrm{mg} / \mathrm{kg}$ ) can be mobilized, the acetic-acid-soluble content being as high as $50-100 \mathrm{mg} / \mathrm{kg}$. At pH 6 or below many crops (e.g. cereals, turnips) fail on these soils: liming to around $\mathrm{pH} 7$ can produce a reasonable crop, although as much as $50 \mathrm{mg}$ nickel per $\mathrm{kg}$ can accumulate in the plant, some 50 times the normal level. Ultrabasic igneous rocks are not abundant in Scotland, and areas of impeded drainage on soils derived therefrom are not of large extent, often less than one hectare, and occur chiefly in Aberdeenshire in north-east Scotland.

The cathode-layer-arc spectrochemical technique, following chemical concentration, is normally used to assess nickel in soil extracts and plant materials, but the first observation of high nickel was made in an acetic-acid extract of a peaty soil overlying ultrabasic rocks in the Aberdeen area by the Lundegårdh flame-emission method.

\section{Copper}

As in most other countries, the copper problems that have arisen in Scotland are seldom straightforward. The earliest direct interest in copper in Scottish soils emerged because of the attribution in 1937 of a disorder of sheep to a deficiency of copper on the light sands of Western Australia. The ataxia, or inco-ordination of movement, in lambs resembled the malady recognized as swayback in Scotland and work on its relationship with soil or herbage copper was soon in progress. While in some occurrences the copper contents of herbage were found to be quite low (below $4 \mathrm{mg} / \mathrm{kg}$ dry matter), in many instances relatively normal levels of copper $(5-10 \mathrm{mg} / \mathrm{kg})$ occurred. Spectrochemical examination showed that in the latter cases the levels of some other trace metals in the soils or plants were often higher than normal: such elements as lead and tin seemed to be involved in the development of swayback on Scottish soils, although no evidence of the involvement of zinc or iron, as suggested elsewhere (see Underwood, 1971), has been found. In all instances the ewes responded to the normal copper therapy and bore healthy lambs after treatment. In this connection it is interesting to note that swayback is reported to be more widespread in Scotland in open, i.e. snow-free winters, during which sheep graze more natural herbage. It has been 
observed that such herbage can carry very high levels of lead during the winter months: up to $40 \mathrm{mg} / \mathrm{kg}$ compared with the $1 \mathrm{mg} / \mathrm{kg}$ common on such soils in summer (see section 'Lead' below). Despite all the indications that some other metal may be involved in swayback the problem of its true cause remains unsolved and unless there is a real deficiency of copper, there is no reliable diagnostic technique for its prediction by soil or plant analysis.

With cattle, true copper deficiency has been confirmed on low copper soils derived from sandstones or other arenaceous rocks, e.g. in Aberdeenshire, while there are numerous occurrences of induced deficiency in cattle resulting from high molybdenum levels in the herbage. These often occur in quite small areas, in which the soil parent material contains some argillaceous rocks and the pedological drainage is generally impeded. Such areas will be discussed further in the section 'Molybdenum'.

Copper deficiency in plants has been observed very widely in cereals, particularly oats (blind-ear) or barley. It is difficult to confirm the cause of the disorder analytically in the mature plant, as the production of grain or leaf appears to be restricted by the amount of copper available, and both healthy and deficient cereal plants have copper contents of around $1.0-2.0 \mathrm{mg} / \mathrm{kg}$, although the yields vary enormously. If samples are taken when the young plants are $15 \mathrm{~cm}$ high, the copper status can generally be assessed, levels below $2.5 \mathrm{mg} / \mathrm{kg}$ being suspect and immediate copper spray treatment desirable; normal plants at this stage contain at least $3-5 \mathrm{mg}$ copper per $\mathrm{kg}$. While pasture herbage shows little or no yield depression from copper deficiency, it, or rather its clover constituent, can be used to assess the copper status of the soil in relation to cereal growth. Little difference in the copper content of grass species (cocksfoot, ryegrass, etc.) can be observed on soils of different copper contents but red clover responds very markedly, varying in content from $<2$ to $>15 \mathrm{mg}$ copper per $\mathrm{kg}$. In Scotland, copper deficiency in cereals can be anticipated if the copper content of red clover grown on the soil in question falls below $4 \mathrm{mg} / \mathrm{kg}$ (Mitchell et al., 1957).

The total copper content of a soil has proved to be little guide to the amount available to plants. Most of the copper-deficient soils in Scotland are mineral soils, with organic matter contents below $10 \%$, derived from fluvioglacial sands or from sandstone or quartzitic rocks. The acetic-acid-soluble copper in a soil has likewise proved to be of little diagnostic value but reasonable relationship has been found between copper content of clover, cereal yield and EDTA-extractable copper in the soil. The deficiency level appears to be around $0.8 \mathrm{mg} / \mathrm{kg}$, but if there is suggestion of a plant (or animal) disorder it is considered prudent to treat with copper if the EDTAextractable level is below $1.5 \mathrm{mg} / \mathrm{kg}$. The normal soil treatment is $20 \mathrm{lb} \mathrm{CuSO}_{4} .5 \mathrm{H}_{2} \mathrm{O}$ per acre $(22 \mathrm{~kg} / \mathrm{ha})$, applied broadcast.

The copper content of plant material can readily be determined spectrochemically by analysis of plant ash in a direct-current arc source. Soil extracts are best examined by the porous-cup solution-spark technique or by atomic absorption. The spectrographic sensitivity of copper is such that preliminary concentration is not required, and indeed contamination problems can make it difficult to apply.

\section{Manganese}

The principal manganese problem on Scottish soils is deficiency in cereals, which occurs largely on the light sandy soils which are often also deficient in several other trace elements, including cobalt, copper, and sometimes even selenium. Manganese, like cobalt, is less available to plants when the soil $\mathrm{pH}$ approaches neutrality, an effect which is not important with copper, unless molybdenum, whose uptake increases in 
such circumstances, is also involved. Manganese deficiency is therefore prevalent on the shell sand soils of the machairs, and it is interesting to note that the black oats which were widely grown in the Western Isles are less susceptible to this deficiency than the common varieties.

The diagnosis of manganese deficiency by analysis of cereal plants is, as is copper, most effective in young plants less than $15 \mathrm{~cm}$ high: contents of $<20 \mathrm{mg}$ manganese per $\mathrm{kg}$ are indicative of deficiency; normal plants contain around $100 \mathrm{mg} / \mathrm{kg}$ at this stage but $<30 \mathrm{mg} / \mathrm{kg}$ at maturity. Levels above $300 \mathrm{mg} / \mathrm{kg}$ in the young plant suggest the possibility of manganese excess, which can arise in very acid soils. The manganese uptake of different species varies very markedly: in a mixed pasture herbage the content in cocksfoot is generally twice that of other species of grass or of clover.

The occurrence of manganese deficiency, when associated with high soil $\mathrm{pH}$, is best treated by spraying or, to some extent, by drilling with the seed, but on such soils there is a considerable danger of rapid immobilization of the manganese. No completely reliable diagnostic soil-test has been established for such soils. On manganesedeficient acid, sandy soils, extraction with neutral ammonium acetate can give a good indication of the mangenese status, less than $2.5 \mathrm{mg} / \mathrm{kg}$ being considered suspect; levels in Scottish soils generally lie between 1 and $50 \mathrm{mg} / \mathrm{kg}$.

Manganese in plant materials is readily determined directly in the ash by directcurrent-arc spectrochemical methods, at the same time as copper and a few other elements such as barium and strontium. For soil extracts, atomic absorption or porouscup solution-spark methods are convenient.

\section{Molybdenum}

The content of molybdenum normally found in Scottish pasture herbage is around $1 \mathrm{mg} / \mathrm{kg}$; this is generally considered to be relatively harmless, irrespective of the copper and sulphate contents. There is no evidence of molybdenum deficiency in agricultural crops although it may possibly arise occasionally in intensive horticulture. There are, however, instances of levels of molybdenum in pasture herbage, particularly in clovers, high enough to affect the copper metabolism of cattle. Some relatively extensive areas have soil carrying herbage with molybdenum contents at the possibly suspect level of $3-5 \mathrm{mg} / \mathrm{kg}$, but instances of herbages with contents of $10 \mathrm{mg} / \mathrm{kg}$ or above are relatively uncommon and widely scattered, from Caithness and Aberdeenshire in the north to Galloway in the south. On such soils, typical symptoms of teart in cattle can be observed and the black Aberdeen Angus can assume a rusty-brown colour, while swayback in sheep may also arise.

The soil on which very high herbage molybdenum contents occur are generally related to shales, slates or argillaceous schists, and total contents of $5-20 \mathrm{mg} / \mathrm{kg}$ molybdenum are not unusual in such soils. The highest availability, as assessed by herbage content, is normally found on soils with poor pedological drainage, and, in mineral soils, only when the soil $\mathrm{pH}$ is near neutrality. In such instances clover contents can approach $50 \mathrm{mg} / \mathrm{kg}$. While the uptake of molybdenum is usually closely related to soil $\mathrm{pH}$, some organic soils (40\% loss-on-ignition) of high acidity ( $\mathrm{pH}$ around 4 ) in Caithness, developed on Old Red Sandstone (Devonian) sediments with abundant argillaceous horizons, can carry clover with molybdenum contents up to $50 \mathrm{mg} / \mathrm{kg}$. Presumably is such instances the available soil molybdenum is organically-bound and not affected by the soil $\mathrm{pH}$.

The most appropriate diagnostic soil extractant would appear to be neutral normal ammonium acetate, levels of extractable molybdenum above $0.1 \mathrm{mg} / \mathrm{kg}$ being suspect, 
but plant analysis is generally preferable, with the molybdenum content of clover being the best index, contents above $5 \mathrm{mg} / \mathrm{kg}$ being considered excessive.

Molybdenum can be determined spectrochemically after chemical concentration, using the cathode-layer-arc technique, but high levels in herbage can be observed directly in plant ash without pretreatment.

\section{Lead}

The lead content of plants grown on Scottish soil generally lies between 0.1 and 1.0 $\mathrm{mg} / \mathrm{kg}$ dry matter, and does not appear to be related to the soil content. After maturity is reached and active growth stops, that is, from autumn onwards, there is a gradual rise in the apparent lead content of all types of plant material. This continues throughout the winter if the herbage persists, and dry-matter levels of lead approaching $40 \mathrm{mg} / \mathrm{kg}$ can be encountered (Mitchell \& Reith, 1966).

Investigations have shown that this is almost certainly due to the deposition of atmospheric lead which adheres to or is absorbed by the plant material when senescent, although not to nearly the same extent when it is growing actively. Such generally distributed atmospheric lead should not be confused with the very local effects that occur adjoining roads with high traffic density. The effect described above also arises in rural areas remote from traffic or industry. It is interesting, in this connection, to note that the surface organic horizons of uncultivated soils from the Scottish moorlands in the north and west can have lead contents approaching $1000 \mathrm{mg} / \mathrm{kg}$ dry matter, although the lead content of the lower mineral horizons is normally no more than $10 \mathrm{mg} / \mathrm{kg}$ and the lead content of calluna $(<10 \mathrm{mg} / \mathrm{kg})$ or other plants $(<2 \mathrm{mg} / \mathrm{kg})$ in the area is not exceptionally high. The explanation must lie in the high deposition of lead in the high rainfall of the area in question and in its fixation in the surface horizon. When lead is incorporated into the soil by atmospheric deposition, as an additive or in plant remains, it, in fact, appears to be immobilized and not subsequently taken up to any appreciable extent by plants.

In consequence no correlation between total or extractable lead in soil and plant uptake has been established, although various soil extractants, including EDTA and acetic acid, have been investigated. Lead in soil extracts and in plants can be determined, simultaneously with other trace elements, by the cathode-layer-arc spectrochemical technique following chemical concentration.

\section{Selenium}

Selenium is known to be essential to animals, but the presence ot a slight excess can lead to severe disorders in many species. Although selenium toxicity occurs on poorly drained organic soils in Ireland, it has not been recorded in Scotland, despite the presence of many argillaceous parent materials in which it might be expected to occur. The problems that arise are due to lack of selenium and can be related to arenaceous soils.

There have been acute cases of enzootic muscular distrophy in cattle on the traceelement-deficient sands along the shores of the Moray Firth in north-east Scotland. This disorder, which often proves fatal, could be largely prevented by a single dose of $15 \mathrm{mg}$ selenium or regular dosage with Vitamin $\mathrm{E}$ or $5 \mathrm{mg}$ selenium (Blaxter et al., 1961).

An extensive survey of the effect of selenium on hill sheep in Scotland (Blaxter, 1963) has indicated that a small but significant increase in live weight could be obtained on many soils derived from arenaceous parent materials. It was suggested 
from these findings that one-tenth of the land area of Scotland was mildly selenium deficient.

The problems of selenium determination at the deficiency level on a routine scale in soils and plants are such that it has not yet been possible to survey the selenium status of Scottish soils, but it is hoped that the forthcoming availability of a sparksource mass-spectrometer may facilitate this. Meantime it is not possible to indicate a method of assessment applicable to Scottish conditions.

\section{Other elements}

The versatile spectrochemical techniques available have enabled the contents of many other trace elements to be monitored when those detailed above were being assessed, whether as total or extractable levels in soils or total contents in plant material. Information is available, in one form or another, for such additional trace elements as zinc, barium, strontium, titanium, vanadium, chromium, tin and silver together with such elements as beryllium, gallium and germanium that are sought but seldom observed. In addition, work is in progress on mercury, cadmium and lithium. In no instance, so far, has any deficiency or toxicity factor been established for these elements under Scottish conditions but the survey is being continued and extended by the improved analytical facilities soon to be available.

\section{Soil classification and characterization}

The very varied and widely scattered occurrences of trace element problems in Scotland are a consequence of the geological complexity of the country already referred to. In the young soils directly related to specific parent materials the total trace element contents can generally be correlated very closely with those of the parent rocks, as there has been little secondary weathering or recycling of materials in the short timeinterval involved. The mobilization of most trace elements, particularly cobalt, nickel and molybdenum (Mitchell, 1964a), can be related very closely with the nature of the soil-forming processes, notably those related to impeded drainage. Nickel and molybdenum excesses, for instance, are to be expected mainly in poorly drained soils on appropriate parent materials and cobalt deficiency is most likely to occur on freely drained soils.

The system of classification that has been adopted in the Soil Survey of Scotland involves the separation of Soil Associations based on the nature of soil parent material, with each association divided into a number of Soil Series related in the main to pedological drainage and degree of podzolization. The laboratory characterization of typical profiles from the series being mapped includes trace element survey of all horizons for total and acetic-acid-soluble contents of up to 25 elements and for ammonium-acetate- and EDTA-extractable contents of selected elements. In the field, the survey of over $90 \%$ of the arable land of Scotland has been completed and systematic soil survey maps, prepared for restricted use on a scale of $1: 25000$, are being published on a scale of $1: 63360$ or, in due course, $1: 50000$.

The survey is already extensive enough to show the value of the correlation of trace element status with soil associations and series. While there can never be an absolute relationship between the occurrence of a trace element disorder and a soil series, because of the variability that inevitably occurs within a series and the arbitrary nature of the boundaries between series on land covered by glacial drift or similar mixed 
deposits compared with soils developed in situ from the underlying rocks, very satisfactory trends can be observed. An adequately experienced soil scientist should be able to interpret the soil survey maps and indicate whether certain trace element disorders are likely to arise on particular soils, taking all the local circumstances, including the nature of the adjoining associations, into account. This is, of course, not a function that can be undertaken by someone who does not appreciate fully the factors involved, and veterinarians and agriculturalists are recommended to consult appropriate soil specialists with a wider experience than soil surveyors, rather than attempt to interpret the maps themselves.

The practical application of the trace element findings is the responsibility of the soil advisory staff of the three Colleges of Agriculture, who cover the North, the East and the West of Scotland. The analytical work is carried out by, or in consultation with, the Macaulay Institute, and uniformity in findings is thereby ensured. In the college areas the correlation between trace element problems and soil type is fully appreciated. It is, for instance, accepted that cobalt deficiency is liable to occur on soils, particularly freely drained soils, of the Boyndie, Corby, Fraserburgh, Countesswells (in part) Hobkirk or Sourhope associations, while copper may be deficient on the Hatton, Boyndie, Corby or Hobkirk associations. On the other hand molybdenum excess can occur locally on poorly drained soils of the Tarves or Thurso associations and nickel toxicity on the Leslie association. The significance of trace element content is in fact such that an analytical finding or a field disorder may indicate an occasional misattribution of a soil to an association. For instance, in soils from lava-rich parent materials, basalt and dolerite are difficult to distinguish in the field but the trace elements differ very markedly.

There are inevitably some very local occurrences of trace element abnormalities, particularly of high contents, that cannot be anticipated from a soil survey map, but, with experience, the possibility of such anomalies in certain soil associations is being appreciated. These can occur especially in zones of mineralization resulting from geological processes.

\section{Spectrochemical methods}

Full details of the established spectrochemical techniques in use at the Macaulay Institute for Soil Research and in the Colleges of Agriculture in the East and West of Scotland, which provide advisory analytical services in these areas, are given in two publications (Mitchell, 1964b; Scott et al., 1971, in the former of which there is a full bibliography of earlier papers. Recent developments in atomic absorption and direct reading techniques have been described by Ure \& Mitchell (1967) and Scott et al. (1969).

The existing facilities at the Macaulay Institute include, apart from normal spectrographic and atomic absorption equipment, two multi-channel Hilger direct-reading spectrometers and a four-channel flame-emission and atomic-absorption instrument for potassium, sodium, calcium and magnesium determinations. The processing of the output from these direct readers is carried out by IBM 1130 digital computer, enabling elaborate corrections for spectral background and interference effects to be made.

In general, direct-current-arc emission, with or without preliminary chemical concentration, is employed for the basic trace element determinations in soils, soil extracts or plant materials, as multielement determinations are possible. Only when one specific 
element is required is an atomic absorption determination preferred, as there is often some advantage in knowing the levels of other elements. For certain specialized determinations arc or spark sources using rotating-pressed-disk or porous-cup solution electrodes are employed.

By these techniques levels down to a fraction of one part per million can be assessed, but there are numerous trace elements whose function, if any, has not been established, which occur in soils and plants at still lower levels. In order to study these, spark-source mass-spectrometric methods are meantime being introduced. With these it is hoped to assess new trace elements at the parts per thousand-million level and take one step further along the path that started in Zürich in 1934.

\section{References}

Blaxter, K. L., 1963. The effect of selenium administration on the growth and health of sheep on Scottish farms. Br. J. Nutr. 17: 105-115.

Blaxter, K. L., E. S. R. McCallum, R. S. Wilson, G. A. M. Sharman \& L. G. Donald, 1961. Prevention of enzootic muscular dystrophy by selenium administration. Proc. Nutr. Soc. 10: vi-vii.

Goldschmidt, M. M., 1954. Geochemistry, 730 pp. (Edited by A. Muir.) Clarendon Press, Oxford.

Greig, J. R., H. Dryerre, W. Godden, A. Crichton \& W. G. Ogg, 1933. Pine: a disease affecting sheep and young cattle. Vet. J. 89: 99-110.

Mitchell, R. L., 1964a. Trace elements in soils. In: F. E. Bear (Ed.), Chemistry of the soil, 2nd ed., Chapter 8, pp. 320-368. Reinhold, New York.

Mitchell, R. L., 1964b. The spectrochemical analysis of soils, plants and related materials. Tech. Commun. Commonw. Bur. Soils (Harpenden, England) No 44A, 225 pp.

Mitchell, R. L., 1972a. Trace elements in soils and factors that affect their availability. Bull. geol. Soc. Am. 85: 1069-1076.

Mitchell, R. L., 1972b. Cobalt in soil and its uptake by plants. IX Simp. int. Agrochim. 'La Fitonutrizione Oligominerale' (Punta Ala, Italy), pp. 521-532.

Mitchell, R. L. \& J. W. S. Reith, 1966. The lead content of pasture herbage. J. Sci. Fd Agric. 17: 437-440.

Mitchell, R. L., J. W. S. Reith \& I. M. Johnston, 1957. Soil copper status and plant uptake. In: Plant analysis and fertilizer problems. Proc. 2nd Colloq. I.R.H.O. (Paris, 1956): 249-259.

O'Brien, D. G. \& R. W. G. Dennis, 1935. Raan or boron deficiency in swedes. Scott. J. Agric. 18: 326-333.

Scott, R. O., J. C. Burridge \& R. L. Mitchell, 1969. Geochemical analysis with a multi-channel direct reader employing direct current arc excitation. Bolet. Geol. Minero, Madrid 80: 446-451.

Scott, R. O. \&. R. L. Mitchell, 1943. Concentration methods in spectrographic analysis. I. J. Soc. chem. Ind., Lond. 62: 4-8.

Scott, R. O., R. L. Mitchell, D. Purves \& R. C. Voss, 1971. Spectrochemical methods for the analysis of soils, plants and other agricultural materials. Consultative Committee for Development of Spectrochemical Work, Bulletin 2. Macaulay Institute for Soil Research, Aberdeen, 87 pp.

Stewart, J., R. L. Mitchell \& A. B. Stewart, 1941. Pining in sheep: its control by administration of cobalt and by use of cobalt-rich fertilizers. Emp. J. exp. Agric. 9: 145-152.

Stewart, J., R. L. Mitchell \& A. B. Stewart, 1942. Pining in sheep II. Emp. J. exp. Agric. 10: 57-60.

Stewart, J., R. L. Mitchell, A. B. Stewart \& H. M. Young, 1946. Solway pine: a marasmic condition in lambs in certain districts of Kirkcudbrightshire. Emp. J. exp. Agric. 14: 145-152.

Underwood, E. J., 1971. Trace elements in human and animal nutrition, 3rd ed. Academic Press, London, 543 pp.

Ure, A. M. \& R. L. Mitchell, 1967. The determination of cobalt in soil extracts by atomic absorption - a study of interference effects. Spectrochim. Acta 23B: 79-96. 